\title{
KEBERKESANAN PENDEKATAN PENGAJARAN BERASASKAN OTAK DALAM MENINGKATKAN KEFAHAMAN PELAJAR TINGKATAN EMPAT TERHADAP PEMBELAJARAN KONSEP DAN MEKANISME FOTOSINTESIS
}

\section{(THE EFFECTIVENESS OF BRAIN BASED TEACHING APPROACH TOWARDS CONCEPTUAL UNDERSTANDING OF CONCEPT AND MECHANISM OF PHOTOSYNTHESIS AMONG FORM FOUR STUDENTS)}

\author{
Fazrin Fazil and Salmiza Saleh \\ School of Educational Studies, Universiti Sains Malaysia, \\ 11800 USM Pulau Pinang, Malaysia \\ *Corresponding author: fazrin_fazil@yahoo.com; salmiza@usm.my
}

Published date: 20 January 2017

To cite this article: Fazrin Fazil, \& Salmiza Saleh. (2016). Keberkesanan pendekatan pengajaran berasaskan otak dalam meningkatkan kefahaman pelajar tingkatan empat terhadap pembelajaran konsep dan mekanisme fotosintesis. Asia Pacific Journal of Educators and Education, 31, 69-83. http://dx.doi.org/10.21315/apjee2016.31.5

To link to this article: http://dx.doi.org/10.21315/apjee2016.31.5

\begin{abstract}
Abstrak:Tujuan kajian ini dijalankan adalah untuk menentukan keberkesanan Pendekatan Pengajaran Berasaskan Otak dalam meningkatkan kefahaman pelajar tingkatan empat terhadap pembelajaran konsep dan mekanisme fotosintesis. Pendekatan ini dilaksanakan berdasarkan prinsip-prinsip Pembelajaran Berasaskan Otak yang dibangunkan oleh Caine dan Caine (1991), Jensen (1996) dan Sousa (1995) dan seterusnya diimplementasikan oleh Salmiza (2008) membentuk Pendekatan Pengajaran Berasaskan Otak. Kajian yang berbentuk kuasi eksperimen ini melibatkan sampel kajian yang terdiri daripada 70 orang pelajar tingkatan empat di dua buah sekolah jenis kebangsaan Cina di Pulau Pinang, Malaysia. Data kajian yang diperoleh melalui pentadbiran Ujian Diagnostik Kefahaman dan Mekanisme Fotosintesis dianalisis secara deskriptif dan inferensi. Hasil kajian menunjukkan Pendekatan Pengajaran Berasaskan Otak berkesan dalam meningkatkan kefahaman pelajar mengenai konsep dan mekanisme fotosintesis. Pelajar yang mengikuti pendekatan ini mempunyai tahap kefahaman konsep
\end{abstract}


dan mekanisme fotosintesis yang lebih baik berbanding dengan pelajar yang menerima pengajaran secara konvensional.

Kata kunci: Pendekatan Pengajaran Berasaskan Otak, kefahaman, fotosintesis

\begin{abstract}
The aim of this study was to assess the effectiveness of Brain Based Teaching Approach towards conceptual understanding of concept and mechanism of photosynthesis among Form Four students. The technique was based on the Brain Based Learning Principles developed by Caine and Caine (1991), Jensen (1996) and Sousa (1995) were then being implemented by Salmiza (2008) in developing a Brain Based Teaching Approach. The effectiveness of the teaching approach within the targeted context would then be assessed in a quasi-experimental research approach involving 70 students from two Science Secondary School in Penang Malaysia. Data collected through the Diagnostic Test of Concept and Mechanism of Photosynthesis was analyzed descriptively and inferentially. The finding of the research showed that this teaching approach was effective in enhancing students' understanding of the concept and mechanism of photosynthesis among students. It was found that students who followed the Brain Based Teaching Approach possessed a better understanding of the concept and mechanism of photosynthesis compared to students who received conventional teaching method.
\end{abstract}

Keywords: Brain Based Teaching Approach, understanding, photosynthesis

\title{
PENDAHULUAN
}

Fotosintesis merupakan satu keperluan asas hidupan. Proses fotosintesis menjadi tunjang utama dalam ekologi iaitu dalam rantai makanan, kitar karbon, aliran tenaga dan sebagainya (Nor Aini, 2003). Maka, guru-guru meletakkan fotosintesis sebagai topik yang paling penting dalam mata pelajaran Biologi (Clegg, 2011). Namun, tahap kefahaman pelajar mengenai konsep fotosintesis berada pada kedudukan sederhana (Clegg, 2011; Md. Nor \& Syed Muammar, 2008). Pelajar sukar menguasai topik fotosintesis selain mempunyai konsep atau idea awal yang salah mengenai topik ini (Wichaidit, Wongyounoi, Dechsri, \& Chaivisuthangkura, 2011; Md. Nor \& Syed Muammar, 2008; Nicklos, 2006).

Berdasarkan kajian-kajian lepas, didapati sebahagian pelajar memiliki idea tentang konsep-konsep Sains yang tidak saintifik, yang disebut sebagai miskonsepsi (Ekici, Ekici, \& Aydin, 2007; Balci, Cakiroglu, \& Tekkaya, 2005). Secara umumnya, kebanyakan pelajar sama ada di peringkat menengah rendah, menengah atas mahupun di peringkat pengajian tinggi mempunyai miskonsepsi mengenai nutrisi tumbuhan, peranan air dalam tumbuhan, perpindahan gas, peranan cahaya dan klorofil dalam fotosintesis dan juga proses respirasi serta transformasi tenaga. Pelajar menganggap fotosintesis itu sendiri adalah respirasi 
bagi tumbuhan (Köse, 2008; Balci et al., 2005). Meskipun begitu, terdapat juga pelajar dalam kajiannya yang menyedari bahawa tumbuhan juga menjalani proses respirasi. Namun, bagi segelintir pelajar ini, mereka berpendapat tumbuhan hanya menjalani respirasi pada waktu malam. Kebanyakan pelajar juga menganggap sumber tenaga bagi tumbuhan ialah air dan mineral yang terdapat pada tanah dan baja merupakan 'makanan' bagi tumbuhan (Köse, 2008). Selain itu, pelajar juga kurang memahami kepentingan karbon dioksida sebagai bahan utama dalam fotosintesis dan juga produk yang dihasilkan dalam proses ini (Clegg, 2011; Wichaidit et al., 2011; Balci et al., 2005).

Satu lagi kajian secara kualitatif yakni melalui kaedah temu bual yang dijalankan oleh Ekici et al. (2007) ke atas 24 orang pelajar sekolah rendah di Turki telah menyenaraikan miskonsepsi pelajar mengenai fotosintesis dengan lebih mendalam. Ekici et al. (2007) melaporkan bahawa rata-rata pelajar menganggap tanah, baja, air dan vitamin sebagai sumber makanan bagi tumbuhan. Malah, ada juga pelajar yang menyatakan bahawa tumbuhan tidak memerlukan makanan. Selain itu, dari aspek definisi fotosintesis, kebanyakan pelajar gagal mendefinisikan fotosintesis dengan tepat. Berikut disenaraikan beberapa definisi yang diutarakan oleh pelajar yang mempunyai miskonsepsi tentang fotosintesis.

1. Fotosintesis ialah respirasi bagi tumbuhan

2. Tumbuhan menukar cahaya matahari kepada makanan melalui fotosintesis

3. Tumbuhan menukar air dan karbon dioksida kepada oksigen melalui fotosintesis

4. Fotosintesis ialah proses tumbuhan menghasilkan tenaga

5. Fotosintesis ialah proses pertukaran gas

6. Fotosintesis ialah proses penghasilan makanan bagi tumbuhan, dengan menggunakan karbon dioksida dan air. Makanan yang dihasilkan dimakan oleh tumbuhan dan air diminum oleh tumbuhan

7. Karbon dioksida dan klorofil dihasilkan di akhir proses fotosintesis

8. Fotosintesis ialah proses penghasilan makanan bagi tumbuhan dengan menggunakan oksigen

9. Fotosintesis ialah proses penghasilan makanan bagi tumbuhan dengan menggunakan karbon dioksida

10. Hanya tumbuhan hijau yang menjalankan fotosintesis

Hasil kajian ini turut disokong oleh dapatan kajian Mhlamvu (2009) yang dijalankan ke atas 200 orang pelajar sekolah menengah di Afrika Selatan bagi mengenal pasti tahap penguasaan pelajar mengenai fotosintesis. Berdasarkan analisis skor pencapaian pelajar dalam ujian diagnostik fotosintesis, Mhlamvu 
(2009) turut menyenaraikan beberapa miskonsepsi yang sama seperti penyelidikpenyelidik sebelum ini. Antaranya ialah:

1. Terma "peringkat gelap" fotosintesis menjadikan pelajar berpendapat bahawa peringkat tersebut berlaku pada waktu malam (dalam keadaan gelap)

2. Fotosintesis ialah proses pertukaran karbon dioksida dan air kepada karbohidrat dan oksigen yang ringkas tanpa mengambil kira peringkatperingkat yang terlibat

Masalah yang sama turut dihadapi oleh pelajar Malaysia, di mana Md. Nor dan Syed Muammar (2008) dalam kajian tinjauan mereka ke atas 102 pelajar tingkatan dua di dua buah sekolah menengah di negeri Selangor mendapati bahawa pelajar umumnya mempunyai tahap kefahaman konsep fotosintesis yang sederhana. Masalah kefahaman konsep fotosintesis ini tidak seharusnya dipandang ringan oleh guru. Hal ini kerana, apabila perkara ini dibiarkan, pelajar akan terus gagal memahami konsep sebenar fotosintesis meskipun mereka sudah berada di peringkat pengajian tinggi. Perkara ini dibuktikan oleh kajian yang dijalankan oleh Nicklos (2006) ke atas pelajar jurusan biologi di salah sebuah universiti tempatan. Dalam kajian tinjauan tersebut, Nicklos (2006) mendapati sebahagian pelajar terlibat mempunyai miskonsepsi dan kurang pengetahuan mengenai konsep fotosintesis meskipun soalan-soalan yang ditanya dalam ujian diagnostik merupakan konsep-konsep asas dalam peringkat cahaya dan peringkat gelap.

Maka, untuk menangani masalah ini, pendekatan pengajaran yang sesuai perlu dilaksanakan. Dalam hal ini, berdasarkan cirinya yang lebih menyeluruh, Pendekatan Pengajaran Berasaskan Otak dilihat berpotensi dalam membantu pelajar mempelajari konsep fotosintesis dengan lebih berkesan.

\section{PENDEKATAN PENGAJARAN BERASASKAN OTAK}

Pendekatan Pengajaran Berasaskan Otak umumnya merupakan strategi pengajaran yang diasaskan berdasarkan prinsip-prinsip pembelajaran berasaskan otak yang dibangunkan hasil daripada perkembangan kajian berkaitan otak. Umumnya semua pembelajaran adalah berasaskan otak, namun dalam konteks kajian ini pengajaran berasaskan otak didefinisikan sebagai teknik yang lebih menghargai fungsi optimum otak berbanding dengan kaedah pengajaran biasa (Caine \& Caine, 1991). 


\section{PRINSIP-PRINSIP PEMBELAJARAN BERASASKAN OTAK}

Hasil daripada perkembangan kajian berkaitan otak, Caine dan Caine (1991), Sousa (1995) dan Jensen (1998) telah memperkenalkan prinsip-prinsip pembelajaran berasaskan otak yang dikelaskan kepada tiga elemen utama serasi otak iaitu keadaan tenang dan peka (relaxed alertness), orkestrasi pelbagai pengalaman yang diperkaya (orchestrated immersion), dan pemprosesan aktif (active processing).

(a) Keadaan yang tenang dan peka - iklim emosi:

1. Otak perlu bersedia untuk pembelajaran yang optimum.

2. Kitar bio-kognitif otak mempengaruhi pembelajaran.

3. Emosi mempengaruhi pembinaan paten oleh otak.

4. Pembelajaran dipertingkat melalui cabaran dan dihalang melalui ancaman.

5. Suasana pembelajaran (dorongan-dorongan serta hubungan) yang positif merangsang fungsi otak

6. Persekitaran, muzik serta aroma yang sesuai merangsang aktiviti otak.

(b) Orkestrasi pengalaman yang diperkaya - pengajaran:

1. Otak adalah unik dan mampu memproses pelbagai perkara secara spontan dalam sesuatu masa.

2. Pencarian maksud (dalam otak) berlaku secara semula jadi melalui proses pembinaan paten.

3. Setiap otak secara spontan dapat memahami dan mencipta bahagianbahagian kecil dan keseluruhan proses/peristiwa yang dilaluinya (fungsi otak kiri dan otak kanan).

4. Pengalaman yang kompleks, aktif serta melibatkan pergerakan merangsang perkembangan otak.

5. Pembelajaran melibatkan keseluruhan fisiologi manusia.

(c) Pemprosesan aktif - pengukuhan:

1. Pembelajaran melibatkan fokus perhatian serta persepsi sempadan/sisi pelajar (peripheral perception).

2. Pembelajaran sentiasa melibatkan kedua-dua proses sedar dan tanpa sedar. 
3. Pembelajaran sentiasa melibatkan sekurang-kurangnya dua pendekatan memori iaitu untuk menyimpan fakta, kemahiran serta prosedur secara berasingan atau making sense of experience.

4. Otak paling mudah memahami dan mengingati fakta-fakta dan kemahiran-kemahiran yang telah sedia ada dalam ruang memori yang semula jadi.

5. Latihan (rehearsal) perlu untuk mengekalkan maklumat dalam otak.

\section{PERLAKSANAAN PENDEKATAN PENGAJARAN BERASASKAN OTAK}

Salmiza (2008) telah membangunkan dan melaksanakan Pendekatan Pengajaran Berasaskan Otak berdasarkan Prinsip-prinsip Pembelajaran Berasaskan Otak dengan menggariskan tujuh fasa pengajaran serasi otak iaitu:

i. Pengaktifan

- Pengetahuan atau konsepsi sedia ada pelajar diaktifkan bagi merangsang pembelajaran sesuatu konsep yang baru. Hal ini kerana konsepsi yang sedia ada sentiasa mempengaruhi proses pengajaran dengan membantu pelajar menyingkirkan perkara-perkara yang tidak berkaitan.

ii. Menjelaskan hasil pembelajaran yang perlu dicapai serta proses pembelajaran terlibat

- Pelajar didedahkan dengan objektif pengajaran serta gambaran menyeluruh tentang pengetahuan atau idea baru yang akan dipelajari. Gambaran menyeluruh tentang idea yang akan diajar kepada pelajar adalah perlu bagi membantu pelajar membina kefahaman yang diinginkan dan memastikan golongan pelajar yang mempunyai kecenderungan kepada otak kanan turut memperolehi faedah daripada aktiviti pengajaran yang bakal dijalankan.

iii. Membuat perkaitan

- Aktiviti menghubung kait konsepsi merupakan tonggak penting kepada pendekatan pengajaran berasaskan otak. Proses ini merangsang otak pelajar untuk membuat hubung kait antara ideaidea yang baru dipelajari dengan konsepsi-konsepsi yang mereka 
sedia ada. Proses membuat hubung kait antara idea-idea ini mendorong otak mencari model mental yang tepat.

iv. Menjalankan aktiviti pembelajaran

- Aktiviti ini memerlukan penglibatan yang menyeluruh oleh setiap pelajar. Pembabitan pelajar secara langsung dalam setiap aktiviti pembelajaran merangsang pemprosesan aktif pelajar dan menjana keberkesanan pembelajaran.

v. Demonstrasi kefahaman pelajar

- Aktiviti demonstrasi kefahaman memberi peluang kepada pelajar untuk menggunakan pengetahuan atau kemahiran baru mereka dalam situasi yang baru. Proses ini memberi masa kepada pelajar untuk berasa selesa dengan konsep yang baru diperolehi dan secara tidak langsung dapat mengukuhkan kefahaman konseptual mereka. Strategi ini melibatkan proses revisit and rehersal terhadap pengetahuan atau kemahiran yang baru dipelajari dan mendorong pemindahan maklumat ke sistem memori jangka panjang pelajar.

vi. Menilai semula ingatan pelajar / Membuat penutup

- Aktiviti penilaian dan penutup memberi peluang kepada pelajar untuk menilai kefahaman serta penerimaan mereka terhadap konsep baru yang telah dipelajari.

\section{vii. Pratonton topik baru}

- Aktiviti pratonton mengenai perkara yang akan berlaku dalam pelajaran yang akan datang memberi ruang kepada otak untuk membuat persediaan tentang tugas pembelajaran yang akan datang dan membantu meningkatkan keberkesanan proses pembelajaran tersebut.

Hasil kajian yang dijalankan di dua buah sekolah menengah di utara Semenanjung Malaysia menunjukkan bahawa perlaksanaan pendekatan ini berkesan dalam meningkatkan kefahaman konsep sains dalam kalangan pelajar.

Kajian-kajian lain yang berkaitan turut menunjukkan bahawa pengajaran berasaskan otak/serasi otak mampu meningkatkan pencapaian pelajar secara umum. Antaranya adalah kajian yang telah dilaksanakan oleh Caulfield, Kidd dan 
Kocher (2000) di sebuah sekolah di Amerika Syarikat bagi mengkaji kesannya ke atas tahap bacaan dan kemahiran metematik pelajar. Dengan memberi tumpuan terhadap empat elemen pembelajaran serasi otak, iaitu persekitaran yang bebas ancaman dan pengalaman aktif pembelajaran, keputusan yang diperoleh daripada kajian ini menunjukkan bahawa pelaksanaan pengajaran berasaskan otak berupaya meningkatkan pencapaian pelajar berbanding dengan sebelumnya. Hasil kajian Bawaneh, Ahmad Nurulazam, Salmiza dan Abd Ghani (2012) turut menunjukkan bahawa pengajaran serasi otak yang dibangun berdasarkan Hermann Whole Brain Model juga berupaya meningkatkan kefahaman dan pencapaian sains dalam kalangan pelajar. Strategi pengajaran serasi otak yang memberikan peluang kepada semua pelajar untuk belajar mengikut gaya berfikir yang bersesuaian dengan mereka ini didapati berupaya mengekalkan perhatian pelajar terhadap pelajaran yang dipelajari.

Di Malaysia, selain Salmiza (2008), didapati hasil kajian Goh (1997) menunjukkan bahawa sistem 4MAT (model pengajaran yang dibangunkan dengan memberi pertimbangan terhadap perkembangan kemahiran kedua-dua otak kiri dan otak kanan pelajar) berkesan dalam meningkatkan pencapaian matematik pelajar. Manakala dapatan Shamsun Nisa (2005) pula menunjukkan bahawa hipermedia (yang dibangunkan serasi dengan struktur otak) memberi kesan yang signifikan terhadap kefahaman dan pencapaian pelajar dalam pembelajaran konsep biologi.

\section{METODOLOGI}

Kajian berbentuk kuasi-eksperimental ini melibatkan 70 orang pelajar tingkatan empat aliran sains tulen di mana 35 orang daripadanya berada dalam kumpulan pelajar yang menerima pengajaran topik fotosintesis melalui Pendekatan Pengajaran Berasaskan Otak (kumpulan eksperimen) manakala 35 orang pelajar lagi menerima pengajaran secara konvensional (kumpulan kawalan). Kedua-dua kumpulan pelajar ini berada dalam kelompok kelas 'A' yang dipilih secara rawak di dua buah sekolah menengah jenis kebangsaan Cina di Pulau Pinang. Kelas 'A' di sini bermaksud kelas yang menempatkan pelajar-pelajar yang cemerlang dalam akademik. Guru-guru yang terlibat dalam kajian ini ialah guru-guru Biologi yang berpengalaman hampir sepuluh tahun dalam pengajaran mata pelajaran Biologi tingkatan empat. Guru yang mengajar kumpulan eksperimen telah diberi penerangan dan demonstrasi mengajar topik fotosintesis berdasarkan Pendekatan Pengajaran Berasaskan Otak sebelum proses intervensi bermula. Pendekatan Pengajaran Berasaskan Otak yang digunakan adalah berdasarkan pendekatan yang dibangunkan oleh Salmiza (2008). 
Kajian ini berjalan selama enam minggu. Tahap kefahaman pelajar mengenai fotosintesis diuji sebelum dan selepas proses pengajaran keseluruhan topik ini. Hal ini dibuat untuk melihat sejauh mana keberkesanan Pendekatan Pengajaran Berasaskan Otak. Tahap kefahaman kedua-dua kumpulan pelajar diuji melalui pentadbiran Ujian Diagnostik Konsep dan Mekanisme Fotosintesis. Pembangunan Ujian Diagnostik Konsep dan Mekanisme Fotosintesis ini dilakukan dengan menggabungkan beberapa jenis item yang diperoleh daripada penyelidik-penyelidik yang lepas. Ujian diagnostik ini secara umumnya terdiri daripada 20 item, yang terdiri daripada 14 item aneka pilihan dan 6 item utama subjektif. Item aneka pilihan ini diubah suai daripada Clegg (2011), Nurul Fareha (2010) dan Nicklos (2006) manakala item subjektif pula diubah suai daripada kajian yang dijalankan oleh Nurul Fareha (2010) dan Mhlamvu (2009) (rujuk lampiran bagi sampel soalan ujian). Data yang diperoleh dianalisis secara deskriptif dan inferensi dengan menggunakan teknik ujian $t$ sampel bebas.

\section{Dapatan Kajian}

Jadual 1 menunjukkan dapatan ujian pra yang ditadbir ke atas kedua-dua kumpulan pelajar eksperimen dan kawalan. Ujian pra ini dibuat seminggu sebelum intervensi berlangsung. Didapati bahawa skor tahap kefahaman awal kedua-dua kumpulan pelajar tentang konsep dan mekanisme fotosintesis adalah hampir setara antara satu sama lain. Malah, skor min bagi pelajar kumpulan eksperimen $(\mathrm{M}=15.11, \mathrm{SD}=7.47)$ dilihat lebih rendah berbanding dengan pelajar kumpulan kawalan $(\mathrm{M}=15.23, \mathrm{SD}=7.29)$.

Jadual 2 menunjukkan hasil analisis ujian Levene dan ujian $t$ sampel bebas bagi ujian pra. Hasil ujian Levene menunjukkan kesemua varians bagi pemboleh ubah bersandar adalah sama atau homogen. Hasil analisis ujian $t$ sampel bebas pula menunjukkan tiada perbezaan yang signifikan dalam skor min kedua-dua kumpulan pelajar mengenai konsep dan mekanisme fotosintesis $(t=-1.41$, $\mathrm{df}=55.26, p=.163$ dan $p>0.05)$. Hal ini bermaksud, kesemua sampel pelajar adalah homogen dan sesuai untuk dijadikan subjek kajian. Maka dengan itu, hasil yang diperoleh dalam ujian pra ini dapat dijadikan asas kepada segala keputusan yang dibuat terhadap kesan pendekatan pengajaran yang ditentukan ke atas kedua-dua kumpulan pelajar. Selain itu, hasil analisis ujian pra ini menjelaskan bahawa sebelum bermulanya intervensi, tahap kefahaman kedua-dua kumpulan pelajar mengenai konsep dan mekanisme fotosintesis adalah rendah kerana mereka masih belum lagi diberi pendedahan mengenai topik ini secara mendalam. 
Jadual 1. Skor min ujian pra Ujian Diagnostik Konsep dan Mekanisme Fotosintesis bagi kumpulan eksperimen dan kumpulan kawalan

\begin{tabular}{lccc}
\hline Kumpulan & Skor min & Sisihan piawai & Ralat min \\
\hline Eksperimen $(\mathrm{N}=35)$ & 15.11 & 7.47 & 1.26 \\
Kawalan $(\mathrm{N}=35)$ & 15.23 & 7.29 & 1.23 \\
\hline
\end{tabular}

Jadual 2. Ujian $t$ sampel bebas skor ujian pra bagi Ujian Diagnostik Konsep dan Mekanisme Fotosintesis bagi kumpulan eksperimen dan kumpulan kawalan

\begin{tabular}{|c|c|c|c|c|c|c|c|c|}
\hline \multicolumn{5}{|c|}{ Ujian Levene } & \multicolumn{4}{|c|}{ Ujian $t$} \\
\hline \multirow{2}{*}{$\mathrm{F}$} & \multirow{2}{*}{ Sig. } & \multirow{2}{*}{$t$} & \multirow{2}{*}{$\mathrm{df}$} & \multirow{2}{*}{$\begin{array}{c}\text { Sig. } \\
\text { (dwi-hujung) }\end{array}$} & \multirow{2}{*}{$\begin{array}{c}\text { Beza } \\
\text { min }\end{array}$} & \multirow{2}{*}{$\begin{array}{l}\text { Beza } \\
\text { ralat min }\end{array}$} & \multicolumn{2}{|c|}{$\begin{array}{l}\text { 95\% Keyakinan } \\
\text { Julat Perbezaan }\end{array}$} \\
\hline & & & & & & & $\begin{array}{c}\text { Had } \\
\text { bawah }\end{array}$ & $\begin{array}{l}\text { Had } \\
\text { atas }\end{array}$ \\
\hline .000 & .983 & -.065 & 68 & .949 & -.114 & 1.765 & -3.636 & 3.407 \\
\hline
\end{tabular}

Selepas enam minggu intervensi berlangsung di mana kumpulan eksperimen menerima pengajaran topik fotosintesis berdasarkan kepada Pendekatan Pengajaran Berasaskan Otak manakala kumpulan kawalan pula menerima pengajaran topik ini melalui pendekatan pengajaran secara konvensional, didapati bahawa tahap kefahaman konsep dan mekanisme fotosintesis telah meningkat dan miskonsepsi pelajar mengenai topik ini telah diatasi. Jadual 3 menunjukkan dapatan ujian pasca yang ditadbir ke atas kedua-dua kumpulan pelajar. Berdasarkan Jadual 3 ini, dapat dilihat bahawa skor min bagi kedua-dua kumpulan pelajar telah meningkat berbanding dengan keputusan ujian mereka dalam ujian pra. Walau bagaimanapun, kumpulan eksperimen $(\mathrm{M}=47.20$, $\mathrm{SD}=1.95)$ memperoleh skor min yang jauh lebih tinggi berbanding dengan kumpulan kawalan $(\mathrm{M}=40.63, \mathrm{SD}=3.78)$.

Jadual 4 menunjukkan hasil analisis ujian $t$ sampel bebas bagi ujian pasca. Dapati bahawa terdapat perbezaan yang signifikan dalam skor min yang dicapai oleh kumpulan eksperimen dengan kumpulan kawalan $(t=9.135, \mathrm{df}=68, p=.000$ dan $p<0.05$ ). Berdasarkan dapatan ini, dapat disimpulkan bahawa Pendekatan Pengajaran Berasaskan Otak lebih efektif dalam meningkatkan kefahaman pelajar mengenai konsep dan mekanisme fotosintesis. Hal ini diyakini kerana elemenelemen yang terkandung dalam Pendekatan Pengajaran Berasaskan Otak amat memberi penekanan kepada penggunaan fungsi otak secara optimum, bukan sahaja semasa proses pengajaran dan pembelajaran berjalan, malahan turut mengambil kira keadaan otak pelajar sebelum dan selepas berlakunya aktiviti pengajaran dan pembelajaran. Keadaan ini dibuat bagi memastikan pelajar mendapat pembelajaran yang maksimum. 
Jadual 3. Skor min ujian pasca Ujian Diagnostik Konsep dan Mekanisme Fotosintesis bagi kumpulan eksperimen dan kumpulan kawalan

\begin{tabular}{lccc}
\hline Kumpulan & Skor min & Sisihan piawai & Ralat min \\
\hline Eksperimen $(\mathrm{N}=35)$ & 47.20 & 1.95 & .330 \\
Kawalan $(\mathrm{N}=35)$ & 40.63 & 3.78 & .639 \\
\hline
\end{tabular}

Jadual 4. Ujian $t$ sampel bebas skor ujian pasca bagi Ujian Diagnostik Konsep dan Mekanisme Fotosintesis bagi kumpulan eksperimen dan kumpulan kawalan

\begin{tabular}{|c|c|c|c|c|c|c|c|c|}
\hline \multicolumn{4}{|c|}{ Ujian Levene } & \multicolumn{3}{|c|}{ Ujian $t$} & & \\
\hline \multirow[b]{2}{*}{$\mathrm{F}$} & \multirow{2}{*}{ Sig. } & \multirow[b]{2}{*}{$t$} & \multirow{2}{*}{$\mathrm{df}$} & \multirow{2}{*}{$\begin{array}{c}\text { Sig. } \\
\text { (dwi-hujung) }\end{array}$} & \multirow[b]{2}{*}{ Beza min } & \multirow{2}{*}{$\begin{array}{c}\text { Beza } \\
\text { ralat min }\end{array}$} & \multicolumn{2}{|c|}{$\begin{array}{l}\text { 95\% Keyakinan } \\
\text { Julat Perbezaan }\end{array}$} \\
\hline & & & & & & & $\begin{array}{c}\text { Had } \\
\text { bawah }\end{array}$ & $\begin{array}{l}\text { Had } \\
\text { atas }\end{array}$ \\
\hline 2.143 & .148 & 9.135 & 68 & .000 & 6.571 & .719 & 5.136 & 8.007 \\
\hline
\end{tabular}

Aras signifikan $p=0.05$

\section{PERBINCANGAN}

Hasil dapatan kajian ini membuktikan Pendekatan Pengajaran Berasaskan Otak berkesan dalam menjana kefahaman pelajar mengenai konsep dan mekanisme fotosintesis sekaligus menangani miskonsepsi mereka tentang topik ini. Keputusan ini secara tidak langsung telah mengesahkan dapatan kajian-kajian lepas bahawa teknik pengajaran dan pembelajaran yang serasi otak berkesan dalam meningkatkan pencapaian kefahaman konseptual pelajar (Salmiza, 2008; Shamsun Nisa, 2005).

Dalam kajian ini, kefahaman konsep pelajar mengenai topik yang ditekankan adalah berdasarkan kepada strategi pengajaran yang serasi otak. Pendedahan kepada pelajar tentang fasa-fasa pengaktifan, menjelaskan hasil pembelajaran yang perlu dicapai serta proses pembelajaran terlibat, membuat perkaitan, menjalankan aktiviti pembelajaran, demonstrasi kefahaman pelajar, menilai semula ingatan pelajar/membuat penutup dan pratonton topik baru telah menjadikan mereka lebih fokus dan juga memberi mereka lebih banyak peluang untuk terlibat secara aktif sepanjang proses pembelajaran berjalan (Salmiza, 2008; Shaw \& Hawes, 1998). Hal ini secara langsung telah menyumbang kepada keadaan yang optimum untuk pelajar belajar.

Konsep pengajaran bagi pendekatan pengajaran ini ialah sentiasa membuat perkaitan antara maklumat baru dengan pengetahuan sedia ada pelajar. Keadaan ini akan menjadikan pelajar lebih peka dengan proses pembelajarannya (White \& Gunstone, 1992). Pengalaman pembelajaran dengan input yang diberi dalam 
pelbagai bentuk iaitu secara visual, audio dan kinestetik dalam persekitaran yang optimum memberi ruang kepada pelajar untuk membuat perkaitan antara maklumat-maklumat yang diperoleh bagi membina makna yang dikehendaki. Makna atau kefahaman yang diperoleh ini seterusnya dikukuhkan dengan mengadakan aktiviti pembelajaran yang memerlukan pelajar untuk terlibat secara aktif (Caine \& Caine, 1991; Jensen, 1996). Aktiviti pembelajaran ini dijalankan secara induktif dan diselitkan juga dengan proses-proses perbincangan, penilaian serta penyelesaian masalah (Sousa, 1995).

Sebagai contoh, dalam mengajar konsep fotosintesis, pada awalnya, pelajar ditunjukkan oleh guru tumbuhan hijau yang sebenar (sebagai contoh pokok kaktus dan pokok bunga raya) dan mereka menyatakan ciri-ciri yang dapat dilihat pada kedua-dua pokok berkenaan. Kemudian, pelajar disarankan untuk membuat perhubungan tentang ciri-ciri yang ada pada tumbuhan-tumbuhan tersebut dengan habitat di mana kebanyakan tumbuhan tersebut hidup dan bagaimana ciri-ciri yang ada pada tumbuhan itu dapat membantunya meneruskan kelangsungan hidup. Fasa orchestrated immersion dalam Pendekatan Pengajaran Berasaskan Otak memberi peluang kepada pelajar untuk mendapat pelbagai aktiviti pembelajaran yang berkaitan dengan fotosintesis. Aktiviti-aktiviti yang diadakan adalah merangkumi pelbagai bentuk iaitu secara visual, audio dan kinestetik. Antara aktiviti-aktiviti yang dibuat ialah menganalisis video dan gambar, menjalankan eksperimen dan menyenaraikan serta membincangkan proses-proses yang berkaitan dengan fotosintesis. Strategi pembelajaran secara aktif dan disokong dengan hubungan yang baik di antara guru dengan pelajar dan juga pelajar dengan pelajar, secara tidak langsung telah merangsang pelajar untuk memproses dan membuat perkaitan segala maklumat yang diperoleh untuk membentuk kefahaman konseptual mereka.

Melihat kepada pelajar yang mengikuti pengajaran topik fotosintesis secara konvensional, pelajar dalam kumpulan ini kurang diberi perhatian dari segi aspek penyediaan pelajar, penekanan terhadap perkaitan antara maklumat baru dengan pengetahuan sedia ada, kepelbagaian pengalaman pembelajaran serta aspek penglibatan aktif pelajar. Proses pengajaran secara konvensional ini adalah proses pengajaran yang berpusatkan guru di mana tumpuan lebih diberikan terhadap aktiviti penerangan konsep dan latihan penyelesaian masalah. Hal ini menyebabkan proses pembelajaran berlangsung dalam keadaan yang kurang memberangsangkan. Pendekatan pengajaran secara konvensional ini tidak menekankan kepada pembinaan makna atau kefahaman konsep dalam minda pelajar. Tiada perkaitan dibuat antara konsep yang diperkenalkan dengan pengetahuan sedia ada pelajar. Keadaan ini menyebabkan maklumat yang diterangkan oleh guru itu terpisah daripada dunia pelajar. Hal ini diyakini merupakan faktor yang menyebabkan pelajar berasa sukar untuk menganalisis maklumat yang diperoleh dengan lebih berkesan. 


\section{KESIMPULAN}

Kajian yang menguji keberkesanan Pendekatan Pengajaran Berasaskan Otak ini tercetus berikutan wujudnya masalah kefahaman konsep dan mekanisme fotosintesis. Didapati bahawa Pendekatan Pengajaran Berasaskan Otak berkesan dalam meningkatkan kefahaman konsep dan mekanisme Fotosintesis pelajar. Kumpulan pelajar yang mengikuti Pendekatan Pengajaran Berasaskan Otak telah memperolehi skor min kefahaman konsep yang lebih tinggi secara signifikan daripada kumpulan pelajar yang menerima pengajaran secara konvensional.

\section{APPENDIX}

1. Which part of plants does photosynthesis takes place?

2. A bean plant needs energy for photosynthesis. Where does that energy come from?

3. Diagram below shows the stages of photosynthesis that occur in the chloroplast.

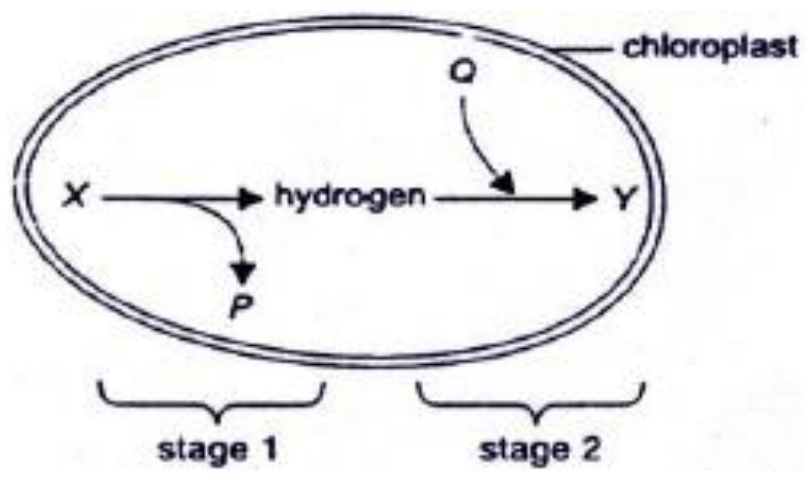

(a) Explain how the increase in the amount of Q affects the synthesis of $\mathrm{Y}$ in stages 2. 


\section{BIBLIOGRAFI}

Balci, S., Cakiroglu, J., \& Tekkaya, C. (2005). Engagement, exploration, explanation, extension and evaluation (5E) learning cycle and conceptual change text as learning tools. The International Union of Biochemistry and Molecular Biology, 34, 199-203.

Bawaneh, A. K., Ahmad Nurulazam, M. Z., Salmiza, S., \& Abd Ghani, K. (2012). Using Herrmann whole brain teaching method to enhance students' motivation towards science learning. Journal of Turkish Science Education, 9(3), 3-22.

Caulfield, J., Kidd, S., \& Kocher, T. (2000). Brain based instruction in action. Educational Leadership, 58(3), 62-65.

Caine, R. N., \& Caine, G. (2003). 12 Brain/mind learning principles in action. The fieldbook for making connections, teaching and the human brain. USA: Corwin Press.

Caine, R. N., \& Caine, G. (1991). Making connections: Teaching and the human brain. Alexandria, VA: Association For Supervision and Curriculum Development.

Clegg, K. J. (2011). Assessing middle and high school students' conceptual understanding about photosynthesis. Maine: The University of Maine.

Ekici F., Ekici E., \& Aydin F. (2007). Utility of concept cartoons in diagnosing and overcoming misconceptions related to photosynthesis. International Journal of Environmental \& Science Education, 2, 111-124.

Goh, C. Y. (1997). Keberkesanan sistem 4MAT dalam pengajaran konsep Matematik. Unpublished Masters thesis, Universiti Sains Malaysia.

Jensen, E. (1996). Brain-based learning. Del Mar, CA: Turning Point Publishing.

Köse, S. (2008). Diagnosing student misconceptions: using drawings as a research method. World Applied Sciences Journal, 3, 283-293.

Mhlamvu, N. H. (2009). Conceptual understanding of photosynthesis. Unpublished Masters thesis, University of Zululand.

Md. Nor, B., \& Syed Muammar, B. (2008). Masalah pembelajaran pelajar sekolah menengah dalam mata pelajaran sains tingkatan 2 tajuk: Fotosintesis, Universiti Teknologi Malaysia. Retrieved from http://eprints.utm.my/10944/1/ Masalah_Pembelajaran_Pelajar_Sekolah_Menengah_Dalam_Mata_Pelajaran_ Sains_Tingkatan_2_Tajuk.pdf

Nicklos, G. (2006). Kekurangan pengetahuan dan miskonsepsi dalam mekanisme fotosintesis di kalangan pelajar sains (biologi) tahun 2, Universiti Pendidikan Sultan Idris. Universiti Pendidikan Sultan Idris.

Nor Aini, A. A. (2003). Keberkesanan pendekatan pengajaran konstruktivis dalam membina semula konsepsi pelajar terhadap konsep-konsep fotosintesis dan makanan. Unpublished doctoral dissertation, Universiti Sains Malaysia.

Nurul Fareha, M. D. (2010). Pengaruh pengajaran dan pembelajaran berdasarkan kepelbagaian potensi kecerdasan pelajar bagi meningkatkan prestasi dalam mata pelajaran Biologi tingkatan empat subtopik Fotosintesis. Universiti Pendidikan Sultan Idris.

Salmiza, S. (2011). The effectiveness of the brain based teaching approach in dealing with problems of form four students' conceptual understanding of Newtonian Physics. Asia Pacific Journal Of Educators And Education, 26, 9-106. 
Salmiza, S. (2010). The effectiveness of brain based teaching approach in dealing with the problems of students' conceptual understanding and learning motivation towards Physics. Proceedings 2nd Paris International Conference on Education, Economy and Society - Paris 21-24 July 2010, 3, 174-185.

Salmiza, S. (2008). Pembangunan dan penilaian keberkesanan modul pendekatan pengajaran berasaskan otak konteks pengajaran fizik tingkatan empat. Unpublished doctoral dissertation, Universiti Kebangsaan Malaysia.

Shamsun Nisa, M. Y. (2005). Kesan hipermedia terhadap pemecutan pembelajaran konsep mitosis. Unpublished doctoral dissertation, Universiti Sains Malaysia.

Shaw, S., \& Hawes, T. (1998). Effective teaching and learning in the primary classroom: A practical guide to brain compatible learning. Leicester: The Services Ltd.

Sousa, D. (1995). How the brain learns. A classroom teacher's guide. Reston, VA: National Association of Secondary School Principals.

White, R. T., \& Gunstone, R. F. (1992). Probing understanding. London: Falmer.

Wichaidit, S., Wongyounoi, S., Dechsri, P., \& Chaivisuthangkura, P. (2011). Using analogy and model to enhance conceptual change in Thai middle school students. US-China Education Review, 8, 333-338. 